Marquette University

e-Publications@Marquette

6-1-2001

\title{
Cross-linking of Polystyrene by Friedel-Crafts Chemistry: Reaction of p-Hydroxymethylbenzyl Chloride with Polystyrene
}

Hongyang Yao

Marquette University

Michael A. McKinney

Marquette University

Caroline Dick

University of Strathclyde

John J. Liggat

University of Strathclyde

C.E. Snape

University of Nottingham

See next page for additional authors

Accepted version. Polymer Degradation and Stability, Vol. 72, No. 3 (June 2001): 399-405. DOI. () 2001 Elsevier B.V. Used with permission. 
Authors

Hongyang Yao, Michael A. McKinney, Caroline Dick, John J. Liggat, C.E. Snape, and Charles A. Wilkie 


\section{Cross-linking of Polystyrene by Friedel- Crafts Chemistry: Reaction of p-hydroxymethylbenzyl Chloride with Polystyrene}

Hongyang Yao

Department of Chemistry, Marquette University

Milwaukee, WI

Michael A. McKinney

Department of Chemistry, Marquette University

Milwaukee, WI

Caroline Dick

Department of Pure and Applied Chemistry,

University of Strathclyde

Glasgow, Scotland

John J. Liggat

Department of Pure and Applied Chemistry,

University of Strathclyde

Glasgow, Scotland

C. E. Snape

School of Chemical, Environmental and Mining Engineering, University of Nottingham

University Park, Nottingham

Polymer Degradation and Stability, Vol 72, No. 3 (June 2001): pg. 399-405. DOI. This article is @ Elsevier and permission has been granted for this version to appear in e-Publications@Marquette. Elsevier does not grant permission for this article to be further copied/distributed or hosted elsewhere without the express permission from Elsevier. 


\title{
Charles A. Wilkie \\ Department of Chemistry, Marquette University \\ Milwaukee, WI
}

\begin{abstract}
Hydroxymethylbenzyl chloride was found to be an effective cross-linking agent for polystyrene. The reaction was found to occur by Friedel-Crafts alkylation between the benzyl alcohol/chloride functional groups in the additive and phenyl ring in polystyrene. The reaction was studied by TGA-IR to monitor the evolution of hydrogen chloride and water, and the structure of the resultant gel was analyzed by solid state NMR and elemental analysis. The potential application in flame-retardancy was evaluated using Cone calorimetry.
\end{abstract}

Keywords: Friedel-Crafts, Polystyrene, Fire retardancy, Cross-linking, Cone calorimetry

\section{I ntroduction}

One of the key steps in the burning of polymeric materials is the release of low molecular weight degradation products from the bulk to the vapor phase as the fuel source. $\underline{1}$ The strategy of cross-linking of polystyrene by Friedel-Crafts reaction has been studied to prevent or postpone this process to achieve thermal stabilization and flame retardancy. $\underline{2}$ The cross-linking temperatures of most systems that have been studied are lower than the processing temperature of polystyrene. $\frac{2-5}{}$ To increase the flame-retardancy of the system, the optimal cross-linking temperature should be higher than the processing temperature (ca. $200-250^{\circ} \mathrm{C}$ ) to be practical and lower than degradation temperature $\left(\mathrm{ca} .360^{\circ} \mathrm{C}\right.$ ) to be useful. Previous work from this laboratory has shown that the incorporation of functional groups (chloride, alcohol, etc.) by copolymerization, which subsequently form a cross-linked product through the Friedel-Crafts alkylation reaction and ultimately lead to the formation of char, is an effective way to stabilize polystyrene. $\frac{6-9}{}$

We have previously reported on the study of multi-functional additives which could cross-link polystyrene at controllable temperature. $\frac{10}{p}$-Hydroxymethylbenzyl chloride was found to be an effective cross-linking agent of polystyrene, and combined with

Polymer Degradation and Stability, Vol 72, No. 3 (June 2001): pg. 399-405. DOI. This article is (C) Elsevier and permission has been granted for this version to appear in e-Publications@Marquette. Elsevier does not grant permission for this article to be further copied/distributed or hosted elsewhere without the express permission from Elsevier. 
appropriate amount of catalyst precursor and inhibitor, the crosslinking temperature was in the desired range of above the processing temperature and below the degradation temperature. In this paper we report on the course of the reaction between $p$-hydroxymethylbenzyl chloride and polystyrene in the presence of both catalysts and inhibitors and the evaluation of the potential of this system for flame retardancy.

\section{Experimental}

\subsection{Materials and instrumentation}

Polystyrene (PS) was obtained from Aldrich Chemical Co., Mw 280,000; high-impact polystyrene (HIPS) was supplied by Dow Chemical as Styron 404; acrylonitrile-butadine-styrene terpolymer (ABS) by Japan Synthetic Rubber Co., Ltd., containing 15 wt.\% acrylonitrile, 40 wt. \% butadiene, and 45 wt.\% styrene; styrenebutadiene-styrene block copolymer (SBS) by Shell as Kraton D1102, containing about $75 \%$ butadiene; and K-resin by Phillips Petroleum as KR01, containing about $25 \%$ butadiene. The phosphate was provided by Solutia Inc., under trade name Santicizer 141, which consists of about 92\% 2-ethylhexyl diphenyl phosphate (DPP). The sample of 2,2,6,6-tetramethyl-4-piperidinol (TMP) was obtained from the Aldrich Chemical Company.

\subsection{Synthesis of 4-(hydroxymethyl) benzyl chloride ( $p$ - $\mathrm{HMBC}) \underline{10}$}

The same preparative scheme as previously reported has been used for this synthesis. 10 This involves the reduction of 4 (chloromethyl)benzoyl chloride by sodium borohydride. The material was analyzed by mass spectroscopy and NMR spectroscopy and the spectroscopic results agree quite well with those previously reported. $\underline{11}$

Samples for solid state NMR spectroscopy and elemental analysis were prepared by heating a quantity of the material under a nitrogen atmosphere in a glass tube to the desired temperature for 30 min. After cooling to room temperature, the samples were removed from the glass tubes and used for the analysis.

Polymer Degradation and Stability, Vol 72, No. 3 (June 2001): pg. 399-405. DOI. This article is @ Elsevier and permission has been granted for this version to appear in e-Publications@Marquette. Elsevier does not grant permission for this article to be further copied/distributed or hosted elsewhere without the express permission from Elsevier. 
A type PL-2 Plasti-Corder Brabender mixer was used to make the blends; typical conditions were $180^{\circ} \mathrm{C}$ for $10 \mathrm{~min}$. Samples for Cone calorimetry, etc., were prepared by compression molding in a heated Carver press. Elemental analysis was performed by Midwest Microlabs.

TGA-FTIR data was obtained using a Cahn TG-131 thermogravimetric analyzer interfaced to a Nicolet Magna 560 infrared spectrometer under inert atmosphere at a scan rate of $10^{\circ} \mathrm{C} / \mathrm{min}$. The mass of samples is in the range of $40-100 \mathrm{mg}$. Solid state NMR spectroscopy was carried out using a Bruker DX200 spectrometer operating at a frequency of $100 \mathrm{MHz}$ for carbon. All experiments were carried out using cross polarization (CP) and magic angle spinning (MAS) at a frequency of $6 \mathrm{kHz}$. Spinning sidebands accounted for up to $16 \%$ of the total aromatic carbon. A recycle delay of $2 \mathrm{~s}$ was used for all experiments. The CP-MAS contact time was optimized at $1 \mathrm{~ms}$ for all experiments.

Cone calorimetry was performed per ASTM E 1354-92 using a Stanton Redcroft/PL Thermal Sciences instrument at $35 \mathrm{KW} / \mathrm{m}^{2}$ in the horizontal orientation. The samples were $3 \mathrm{~mm}$ thick and mounted using the edge retainer frame and wire grid; the mass was approximately $32 \mathrm{~g}$. Exhaust flow was set at $24 \mathrm{l} / \mathrm{s}$ and the spark was continuous until the sample ignited.

\section{Results and discussion}

\subsection{Characterization of the degradation of a blend of p-hydroxymethylbenzyl chloride ( $p$-HMBC) and polystyrene (PS) by TGA/FTIR}

Based upon previous work on Friedel-Crafts chemistry on polystyrene, one would expect that an activated alkyl halide would alkylate the aromatic rings of polystyrene in a thermal reaction in the absence of a catalyst. This would actually be an autocatalytic reaction in that the evolved $\mathrm{HCl}$ would catalyze further reaction. One may further anticipate that in the presence of an amine, the evolved hydrogen chloride will be absorbed by the amine and the reaction will be retarded. Finally, the presence of a suitable catalyst should

Polymer Degradation and Stability, Vol 72, No. 3 (June 2001): pg. 399-405. DOI. This article is @ Elsevier and permission has been granted for this version to appear in e-Publications@Marquette. Elsevier does not grant permission for this article to be further copied/distributed or hosted elsewhere without the express permission from Elsevier. 
accelerate the reaction. Most of these expectations were found to be true in an examination of the mixture by TGA/FTIR. The TGA and $\mathrm{H}_{2} \mathrm{O} / \mathrm{HCl}$ profiles of blend of polystyrene/p-HMBC/DPP/TMP are shown in Fig. 1. It is clear that the degradation occurs in two steps. The first step, $230-300^{\circ} \mathrm{C}$, involves the loss of about $10 \%$ of the total mass and the evolved gases are water and hydrogen chloride. This confirms that the Friedel-Crafts reaction occurs in this temperature region, and it is clear that the Friedel-Crafts reaction is complete before the degradation of polystyrene commences. The second step of the degradation occurs between 360 and $480^{\circ} \mathrm{C}$ and involves the loss of about $85 \%$ of the mass. The products are the typical aromatic materials which arise from the degradation of polystyrene ${ }^{12}$ and additional water is evolved. The evolution of water in this second step is only observed when DPP is present and, therefore, it is attributed to the dehydration of the diphenylphosphoric acid.

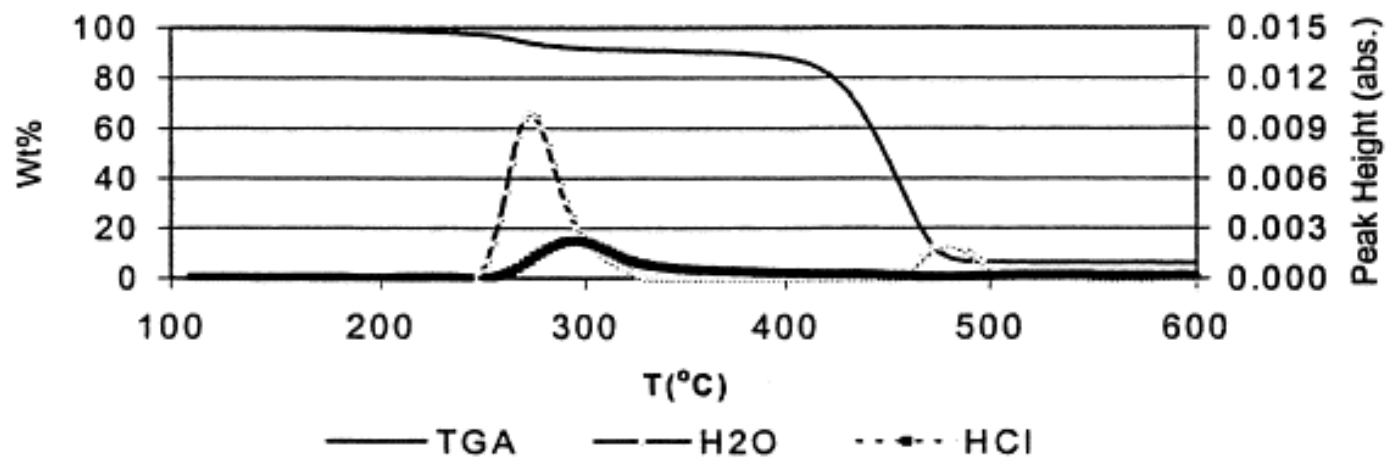

Fig. 1. TGA and $\mathrm{H}_{2} \mathrm{O} / \mathrm{HCl}$ profiles of blends of PS/HMBC/DPP/TMP.

The $\mathrm{H}_{2} \mathrm{O} / \mathrm{HCl}$ profiles of various blends are shown in Figs. 2 and $\underline{3}$ and the data concerning the onset of the evolution and the temperature at which the peak evolution is observed are collected in Table 1.

Polymer Degradation and Stability, Vol 72, No. 3 (June 2001): pg. 399-405. DOI. This article is (C) Elsevier and permission has been granted for this version to appear in e-Publications@Marquette. Elsevier does not grant permission for this article to be further copied/distributed or hosted elsewhere without the express permission from Elsevier. 
NOT THE PUBLISHED VERSION; this is the author's final, peer-reviewed manuscript. The published version may be accessed by following the link in the citation at the bottom of the page.

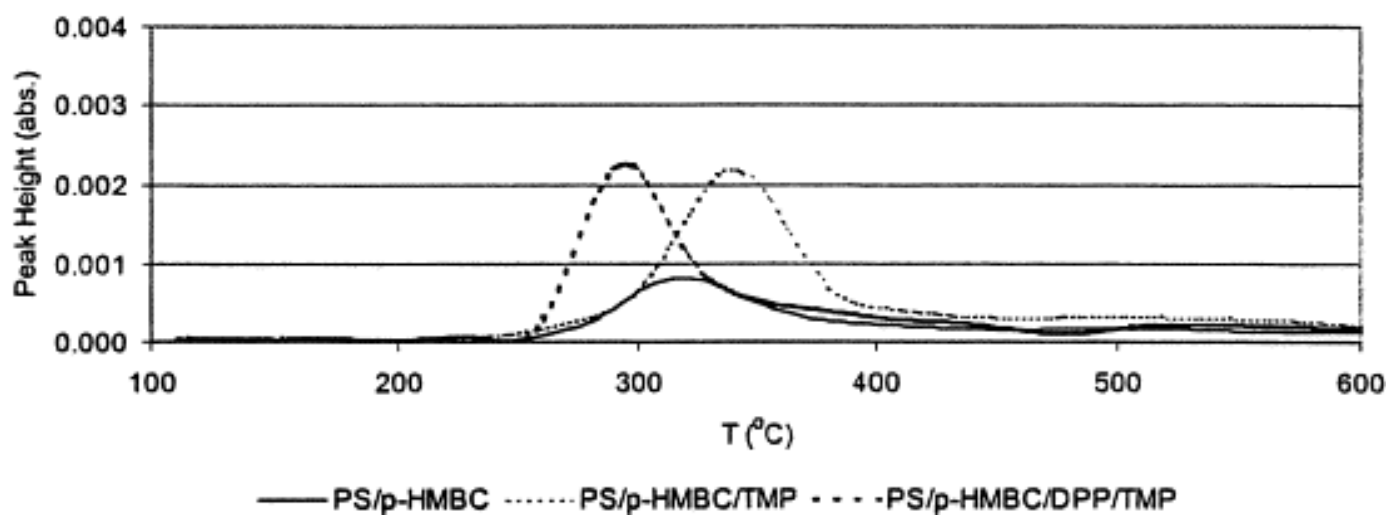

Fig. 2. $\mathrm{HCl}$ profiles of PS blends.

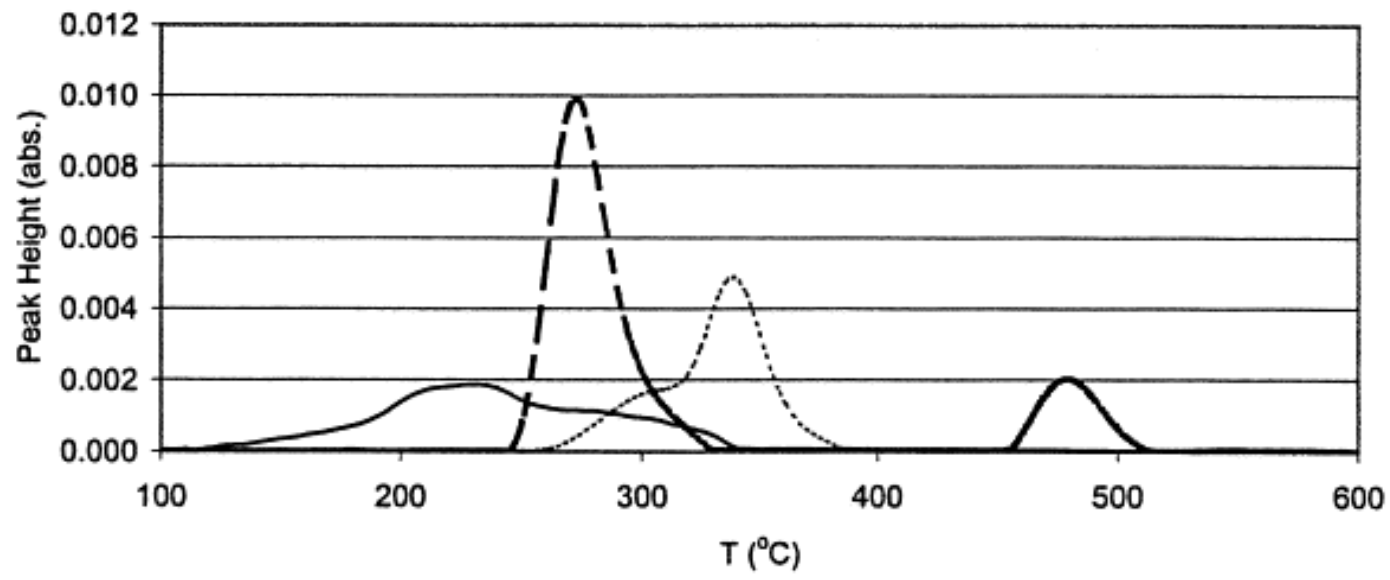

PS/p-HMBC …. PS/p-HMBC/TMP - -PS/p-HMBC/DPP/TMP

Fig. 3. $\mathrm{H}_{2} \mathrm{O}$ profiles of PS blends.

Table 1. Evolution of water and hydrogen chloride from the mixtures of polystyrene and hydroxymethylbenzyl chloride alone and in the presence of additives

\section{Sample}

\section{Onset temperature of the evolution $\left({ }^{\circ} \mathrm{C}\right)$}

\section{Peak temperature of the evolution $\left({ }^{\circ} \mathrm{C}\right)$}

Evolution of hydrogen

chloride

$\begin{array}{lll}\text { PS+HMBC } & 150 & 320 \\ \text { PS+HMBC+TMP } & 260 & 340 \\ \text { PS+HMBC+TMP+DPP } & 250 & 290 \\ \text { Evolution of water } & & \\ \text { PS+HMBC } & 130 & 230 \\ \text { PS+HMBC+TMP } & 260 & 340 \\ \text { PS+HMBC+TMP+DPP } & 245 & 270\end{array}$

Polymer Degradation and Stability, Vol 72, No. 3 (June 2001): pg. 399-405. DOI. This article is @ Elsevier and permission has been granted for this version to appear in e-Publications@Marquette. Elsevier does not grant permission for this article to be further copied/distributed or hosted elsewhere without the express permission from Elsevier. 
NOT THE PUBLISHED VERSION; this is the author's final, peer-reviewed manuscript. The published version may be accessed by following the link in the citation at the bottom of the page.

One can see that in each case the onset temperature of the evolution is roughly comparable for both water and hydrogen chloride. It is somewhat difficult to define an onset temperature for the evolution of decomposition products. It is defined here as the temperature at which absorbance at that frequency characteristic of the evolved molecule begins to show substantial increase. The most likely explanation for these results is that a small amount of $\mathrm{HCl}$ is initially lost and this catalyzes the Friedel-Crafts reaction. In the presence of TMP the first molecules of $\mathrm{HCl}$ are absorbed by the amine and therefore the onset temperature of the gases $\left(\mathrm{HCl}\right.$ and $\left.\mathrm{H}_{2} \mathrm{O}\right)$ is delayed since there is no catalyst present. When DPP is also present, the onset temperature is slightly lower and corresponds rather well to the temperature at which DPP undergoes degradation to give the acid catalyst. $\underline{7}$

The peak shapes are quite different for the degradation in the absence of additives versus that in the presence of either only TMP or with both TMP and DPP. Integration of the area under the curve provides the information that approximately the same amount of water is lost in each case; the amount of $\mathrm{HCl}$ is also constant for all three cases. Thus the amount of gas evolved is not effected by the presence of the catalyst, but the temperature at which it is lost is effected. In order to compare the relative yields of $\mathrm{H}_{2} \mathrm{O}$ and $\mathrm{HCl}$, the observed spectroscopic intensities need to be normalized with respect to relative transition intensities, i.e. extinction coefficients. Due to the resolution of the instrument, each of the observed peaks corresponds to a convolution of multiple spectroscopic transitions. Spectral line intensities, corrected for temperature, were obtained for each individual spectroscopic transition. No correction was made for pressure broadening. For hydrogen chloride, the peak at $2727 \mathrm{~cm}^{-1}$ encompasses two individual peaks, one from each of the chlorine isotopes, and the summed spectral line intensities for these is $2.69 \times 10^{-19} \mathrm{~cm}^{-1} / \mathrm{mol}-\mathrm{cm}^{-2}$. For water, the peak at $3854 \mathrm{~cm}^{-1}$ was used and this band contains many individual transitions, when summed this gives a spectral line intensity of $4.02 \times 10^{-19} \mathrm{~cm}^{-1} / \mathrm{mol}$ $\mathrm{cm}^{-2}{ }_{13}$ If one divides the observed intensities by the sum of the appropriate spectral line intensity factors, there is approximately 1.07 mol of water evolved for every $\mathrm{mol}$ of $\mathrm{HCl}$ evolved. Considering the experimental uncertainties in the absorbances and the approximations

Polymer Degradation and Stability, Vol 72, No. 3 (June 2001): pg. 399-405. DOI. This article is (C) Elsevier and permission has been granted for this version to appear in e-Publications@Marquette. Elsevier does not grant permission for this article to be further copied/distributed or hosted elsewhere without the express permission from Elsevier. 
in the extinction coefficients, this may be considered to indicate that the same amount of each gas is evolved.

The best explanation of these results is that the chloride and alcohol portions of the molecule have an equal possibility of undergoing the Friedel-Crafts reaction. This leads to a functionalized polystyrene in which some of the aromatic rings that have been alkylated possess an alcohol functionality while others have a chloride functionality. Once the polystyrene is alkylated, the mobility of the new functionalized polymer is greatly diminished. A significantly higher temperature is required for this functionalized polymer to encounter and then alkylate a new ring to produce a cross-linked polymer. The evolution of both $\mathrm{H}_{2} \mathrm{O}$ and $\mathrm{HCl}$ occurs over a temperature range which varies between more than $300^{\circ} \mathrm{C}$ in the widest to somewhat more than $100^{\circ} \mathrm{C}$ at the narrowest. This is depicted below in Scheme 1.
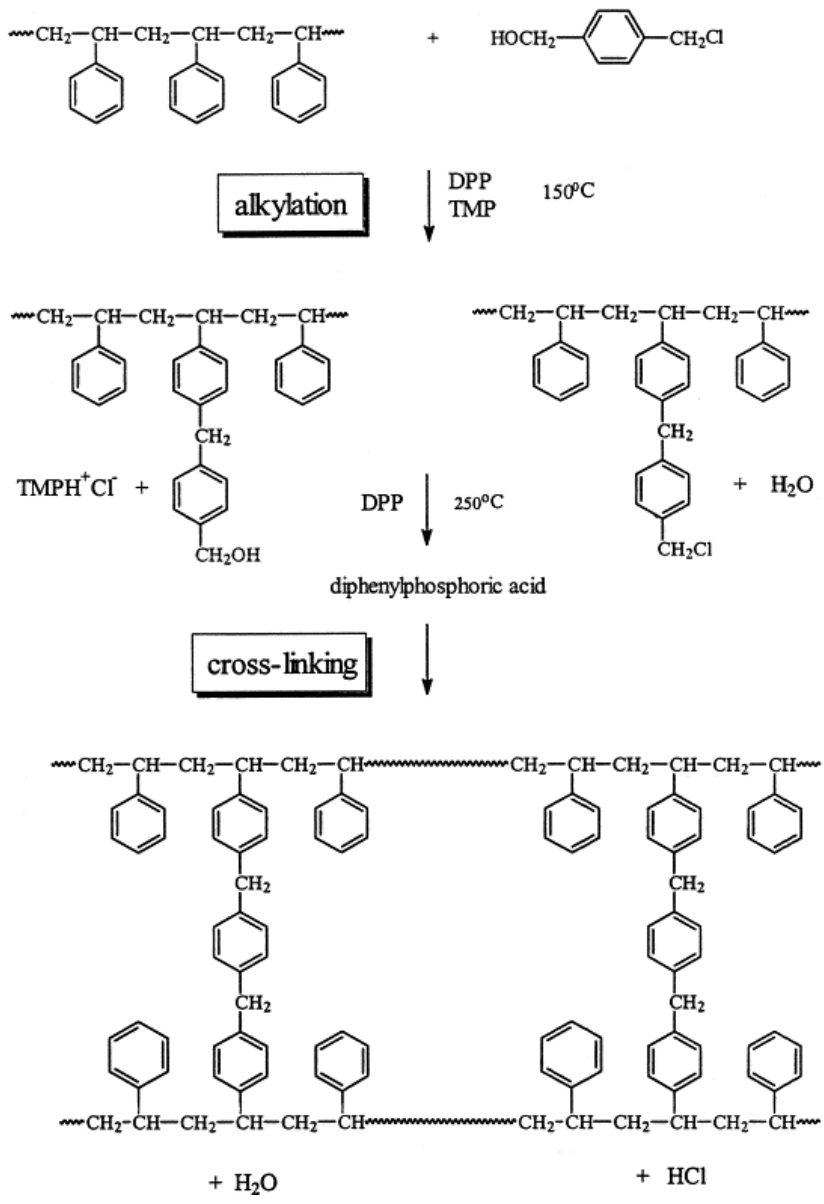

Scheme 1. Alkylation and cross-linking of polystyrene with HMBC in the presence of TMP and DPP as catalyst.

Polymer Degradation and Stability, Vol 72, No. 3 (June 2001): pg. 399-405. DOI. This article is @ Elsevier and permission has been granted for this version to appear in e-Publications@Marquette. Elsevier does not grant permission for this article to be further copied/distributed or hosted elsewhere without the express permission from Elsevier. 


\subsection{Characterization of the functionalized and cross- linked structure}

A blend of polystyrene, the alkylating agent, and the amine was prepared by solution mixing and then characterized by elemental analysis and solid state NMR spectroscopy. The elemental analysis results are shown in Table 2 . One sees that alkylation occurs at $200^{\circ} \mathrm{C}$ and that somewhat more of the oxygen reacts initially than does the chloride but at $250^{\circ} \mathrm{C}$ more of the chloride is lost than the oxygen. After $5 \mathrm{~h}$ at $300^{\circ} \mathrm{C}$ all of the chloride and the alcohol have been lost and a cross-linked matrix is obtained. The mixture after heating at $200^{\circ} \mathrm{C}$ is completely soluble and thus only alkylation has occurred, without cross-linking. At higher temperatures insolubility results which indicates that a cross-linked structure has been produced.

Table 2. Elemental analysis of blends of PS, HMBC and TMP as a function of heating

$\begin{array}{lllllll}\text { Sample no. } & \mathbf{T}\left({ }^{\circ} \mathbf{C}\right) & \text { Time (h) } & \mathbf{C ~ ( \% ) ~} & \text { H (\%) } & \mathbf{C l}(\%) & \text { O (\%) } \\ 1 & - & 0 & 89.21 & 7.50 & 2.23 & 1.02 \\ 2 & 200 & 0.5 & 89.50 & 7.62 & 1.99 & 0.71 \\ 3 & 250 & 0.5 & 90.46 & 7.72 & 1.12 & 0.60 \\ 4 & 300 & 0.5 & 91.71 & 7.70 & 0.49 & 0.05 \\ 5 & 300 & 5.4 & 92.34 & 7.67 & \sim 0 & \sim 0\end{array}$

\subsection{Solid state NMR}

The same samples which were analyzed by elemental analysis were also subjected to solid state ${ }^{13} \mathrm{C}-\mathrm{NMR}$ analysis; the spectra as a function of temperature are shown in Fig. 4. I nitially one observes two peaks in the aromatic region, which may be assigned to the nonprotonated and protonated carbons of both polystyrene and HMBC, and a broad peak in the aliphatic region, attributable to the methylene and methine carbons. It is only at $400^{\circ} \mathrm{C}$, and higher temperature, that a change is apparent in the spectrum. The first observation that may be made is the increased width of the peaks, indicative of chain rigidity due to a high cross-link density. One can also observe that both the aromatic and the aliphatic peaks have decreased in intensity with the aliphatic carbon peaks disappearing much faster than the aromatic carbon peaks. This is indicative of the charring reaction which

Polymer Degradation and Stability, Vol 72, No. 3 (June 2001): pg. 399-405. DOI. This article is (C) Elsevier and permission has been granted for this version to appear in e-Publications@Marquette. Elsevier does not grant permission for this article to be further copied/distributed or hosted elsewhere without the express permission from Elsevier. 
occurs at high temperatures. In previous work we have reported on a radiative gasification experiment in which one is able to degrade the polymer in a nitrogen atmosphere and, using a video camera, record the degradation process. In these experiments we observed the charring process for a related system. $\underline{8}$

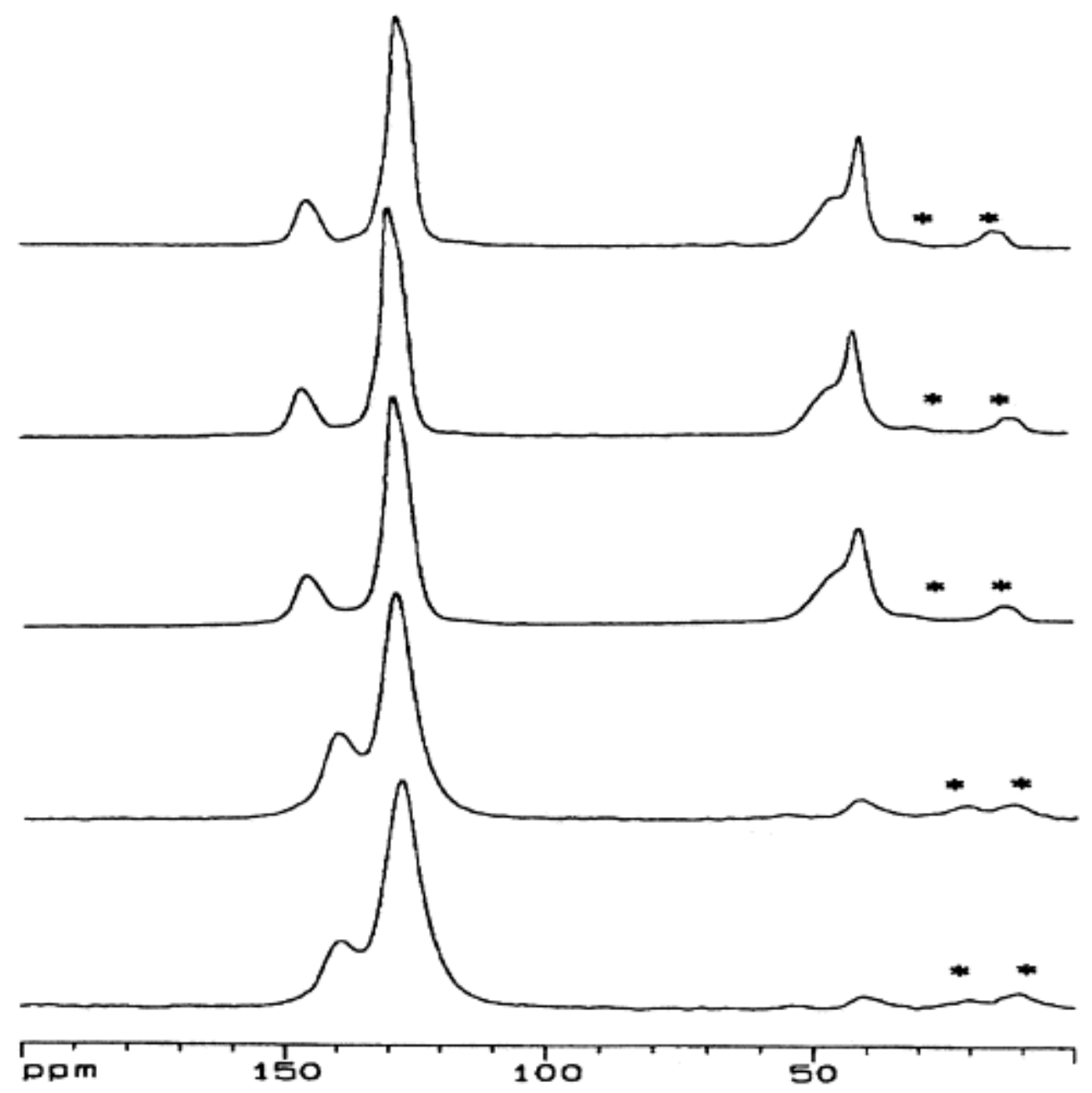

Fig. 4. Solid state NMR of blends of polystyrene and $\mathrm{p}-\mathrm{HMBC}$, after treatment at: (a) no treatment, (b) $300^{\circ} \mathrm{C}, 0.5 \mathrm{~h}$, (c) $300^{\circ} \mathrm{C}, 5.4 \mathrm{~h}$, (d) $400^{\circ} \mathrm{C}, 1 / 2 \mathrm{~h}$, (e) flame treatment in air, $0.1 \mathrm{~h}$. Spinning sidebands are indicated by *.

\subsection{Evaluation of flame retardancy}

The flame retardancy of multi-functional additives was evaluated by Cone calorimetry and the results are presented in Table 3. The total energy that is released is not shown in the table but it is quite comparable for all samples and this indicates that a 
condensed phase process is occurring in all cases. Discussing all of the parameters in turn one finds that the time to ignition is adversely effected by the presence of the additives while the time to burnout may be slightly increased. It is very significant to note the significant reduction in the peak heat release rate, $\mathrm{PHRR}$; the greatest reduction occurs for the combination of HMBC in the presence of both the amine and the catalyst but a reduction is observed in all cases. This change is shown in Fig. 5 , which includes the peak heat release rate data for the virgin polymers and their blends with $\mathrm{HMBC}$ and the two necessary additives to affect the most efficacious reaction. Likewise there is always a reduction in the mass loss rate and the fraction of mass which is lost at burnout is always lower in the presence of the amine and catalyst. Finally we note that the extinction area, and the specific extinction area, both of which are a measure of smoke formation, do not change significantly for any system. This means that additional smoke is not generated by these systems. It must be noted that all these samples give no rating in the UL- 94 test. If the loading of HMBC is increased to $20 \%$ a V-2 rating is possible. Further work will be performed using this system, which is quite efficacious in reducing the rate of heat release, with other additives designed to reduce the ignitiability of the polymer.

Table 3. Cone calorimetric data for various systems at $35 \mathrm{~kW} / \mathrm{m}^{2}$ heat flux

\begin{tabular}{|c|c|c|c|c|c|c|c|c|c|}
\hline Polymer & $\begin{array}{c}\text { Cross- } \\
\text { linking } \\
\text { agent } \\
\text { (CRA) }\end{array}$ & CRA/ TMP/ DPP & $\begin{array}{l}\text { Time to } \\
\text { ignition } \\
\text { (s) }\end{array}$ & $\begin{array}{c}\text { Time to } \\
\text { burnout } \\
\text { (s) }\end{array}$ & $\begin{array}{c}\text { PHRR } \\
\left(\mathrm{kW} / \mathrm{m}^{2}\right)\end{array}$ & $\begin{array}{c}\text { Time } \\
\text { to } \\
\text { PHRR } \\
\text { (s) }\end{array}$ & $\begin{array}{c}\text { Mass } \\
\text { loss } \\
\text { rate, } \\
\text { ( } \mathbf{m g} / \mathbf{s})\end{array}$ & $\begin{array}{c}\text { Mass } \\
\text { loss at } \\
\text { burnout } \\
(\%)\end{array}$ & $\begin{array}{l}\text { Extinction } \\
\text { area }\left(\mathrm{m}^{2}\right)\end{array}$ \\
\hline PS & - & $-1-1-$ & 50 & 222 & 747 & 185 & 162 & 83 & 37 \\
\hline PS & HMBC & $10.0 / .10 / 0$ & 25 & 228 & $520(29)$ & 195 & 148 & 90 & 46 \\
\hline PS & HMBC & $10.0 / .10 / 5.0$ & 30 & 240 & $365(51)$ & 115 & 112 & 63 & 51 \\
\hline PS & DCPX & $10.0 / .10 / 0$ & 35 & 225 & $570(24)$ & 195 & 154 & 87 & 47 \\
\hline PS & DCPX & $10.0 / .10 / 5.0$ & 35 & 220 & $512(31)$ & 175 & 165 & 83 & 56 \\
\hline HIPS & - & $-1-1-$ & 75 & 231 & 916 & 190 & 184 & 83 & 39 \\
\hline HIPS & HMBC & $10.0 / 0 / 5.0$ & 35 & 240 & $352(62)$ & 220 & 108 & 70 & 47 \\
\hline HIPS & HMBC & $10.0 / .10 / 5.0$ & 25 & 240 & $348(62)$ & 80 & 101 & 57 & 66 \\
\hline HIPS & DCPX & $10.0 / 0 / 5.0$ & 35 & 225 & $532(42)$ & 150 & 159 & 83 & 52 \\
\hline HIPS & $\mathrm{DCPX}$ & $10.0 / .10 / 5.0$ & - & 226 & $526(43)$ & 180 & 152 & 80 & 58 \\
\hline HIPS & Diol & $20.0 / 0 / 5.0$ & - & 240 & $315(66)$ & 120 & 93 & 60 & 54 \\
\hline ABS & - & $-1-1-$ & - & 187 & 1195 & 150 & 262 & 87 & 26 \\
\hline ABS & $\mathrm{HMBC}$ & $10.0 / .10 / 5.0$ & - & 203 & $675(44)$ & 140 & 178 & 86 & 52 \\
\hline ABS & DCPX & $10.0 / .10 / 5.0$ & - & 209 & $715(40)$ & 140 & 178 & 86 & 57 \\
\hline SBS & - & $-1-1-$ & - & 158 & 1368 & 135 & 256 & 84 & 41 \\
\hline SBS & $\mathrm{HMBC}$ & $10.0 / .10 / 5.0$ & - & 143 & $1131(17)$ & 130 & 271 & 85 & 45 \\
\hline SBS & $\mathrm{DCPX}$ & $10.0 / .10 / 5.0$ & - & 134 & $1110(19)$ & 105 & 269 & 85 & 49 \\
\hline K-resin & - & $-1-1-$ & 50 & 166 & 754 & 185 & 302 & 81 & 80 \\
\hline
\end{tabular}

Polymer Degradation and Stability, Vol 72, No. 3 (June 2001): pg. 399-405. DOI. This article is @ Elsevier and permission has been granted for this version to appear in e-Publications@Marquette. Elsevier does not grant permission for this article to be further copied/distributed or hosted elsewhere without the express permission from Elsevier. 
NOT THE PUBLISHED VERSION; this is the author's final, peer-reviewed manuscript. The published version may be accessed by following the link in the citation at the bottom of the page.

\begin{tabular}{|c|c|c|c|c|c|c|c|c|c|}
\hline Polymer & $\begin{array}{l}\text { Cross- } \\
\text { linking } \\
\text { agent } \\
\text { (CRA) }\end{array}$ & CRA/ TMP/ DPP & $\begin{array}{c}\text { Time to } \\
\text { ignition } \\
\text { (s) }\end{array}$ & $\begin{array}{l}\text { Time to } \\
\text { burnout } \\
\text { (s) }\end{array}$ & $\begin{array}{c}\text { PHRR } \\
\left(\mathbf{k W} / \mathbf{m}^{2}\right)\end{array}$ & $\begin{array}{c}\text { Time } \\
\text { to } \\
\text { PHRR } \\
\text { (s) }\end{array}$ & $\begin{array}{l}\text { Mass } \\
\text { loss } \\
\text { rate, } \\
\text { ( } \mathbf{m g} / \mathbf{s})\end{array}$ & $\begin{array}{c}\text { Mass } \\
\text { loss at } \\
\text { burnout } \\
(\%)\end{array}$ & $\begin{array}{l}\text { Extinction } \\
\text { area }\left(\mathrm{m}^{2}\right)\end{array}$ \\
\hline K-resin & $\mathrm{HMBC}$ & $10.0 / .01 / 5.0$ & - & 215 & $588(22)$ & 185 & 164 & 84 & 54 \\
\hline K-resin & DCPX & $10.0 / .10 / 5.0$ & - & 195 & 647 (14) & 160 & 200 & 88 & 50 \\
\hline
\end{tabular}

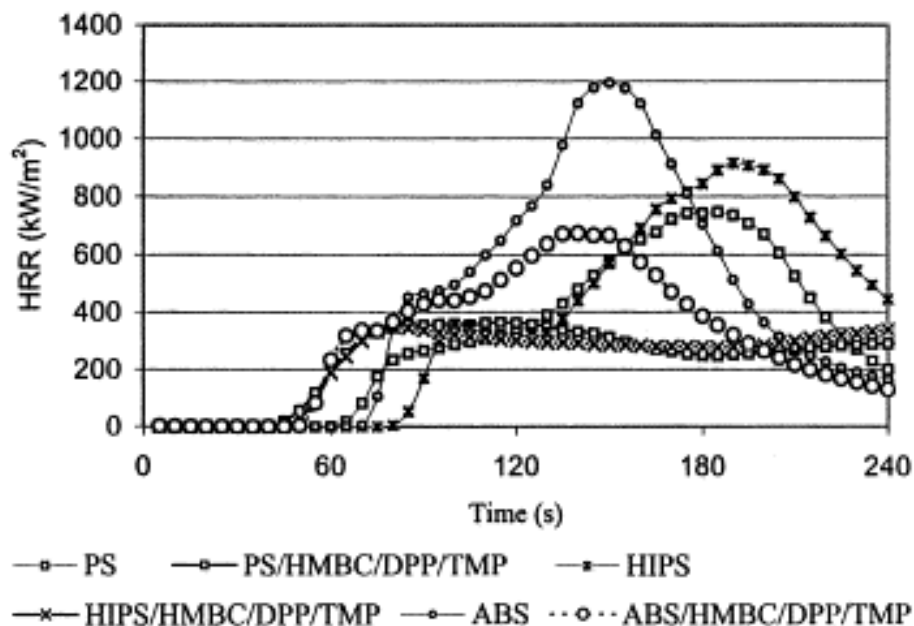

Fig. 5. Heat release rate of cone calorimetry of styrenic polymers and their blends.

\section{Conclusions}

The reaction proceeds most smoothly when two additives, a phosphate ester and a hindered amine are present. The hindered amine functions as a base to consume the hydrogen chloride liberated by the first alkylation, thus removing a catalyst which would facilitate cross linking at a relatively temperature to produce an acid catalyst, which can then function as the cross linking catalyst, as desired, at this higher temperature.

\section{Acknowledgements}

This work was supported partially by the Albemarle Corporation. The kind cooperation of Dun Chen and Cahn Instruments in making their TGA/FTIR equipment available is gratefully acknowledged. Marcel van der Berk and David Paul at Solutia graciously provided the Cone calorimetry data.

\section{References}

${ }^{1}$ Nelson GL. Fire and polymers. An overview. In: Nelson GL, editor. ACS symposium series 599, fire and polymers II - materials and tests for hazard prevention. Washington (DC): American Chemical Society. 
NOT THE PUBLISHED VERSION; this is the author's final, peer-reviewed manuscript. The published version may be accessed by following the link in the citation at the bottom of the page.

2N. Grassie, L. Gilks. J. Polym. Sci. Polym. Chem. Ed., 11 (1973), p. 1985 3S.K. Brauman, J. Polym. Sci. Polym. Chem. Ed., 17 (1979), p. 1129

4j.F. Rabek, L. Lucki, J. Polym. Sci. Part A: Polym. Chem., 26 (1988), p. 2537

${ }^{5}$ Khanna YP, Pearce EM. In: Levin M, Atlas SM, Pearce EM, editors. Flameretardant polymeric materials, vol. 2. Plenum Press, 1978, p. 43-60.

6f. Li, C.A. Wilkie, Polym. Degrad. Stab., 57 (1997), p. 293

zZ. Wang, D.D. Jiang, M.A. McKinney, C.A. Wilkie, Polym. Degrad. Stab., 64 (1999), p. 387

8Z. Wang, D.D. Jiang, C.A. Wilkie, J.W. Gilman, Polym. Degrad. Stab., 66 (1999), p. 373

9. Zhu, M.A. McKinney, C.A. Wilkie, Polym. Degrad. Stab., 66 (1999), p. 213

10Yao H, Zhu J, McKinney MA, Wilkie CA. J. Vinyl Add Tech, 2000; 6:205.

11M.E. Pierce, G.D. Harris, Q. Islam, L.A. Radesca, L. Storace, R.E.etal. Waltermire, J. Org. Chem., 61 (1996), p. 444

12M. Suzuki, C.A. Wilkie, Polym. Degrad. Stab., 47 (1995), p. 217

$\underline{13}$ L.S. Rothman, C.P. Rinsland, A. Goldman, S.T. Massie, D.P. Edwards, J.-M. Flaud, et al. J. Quant. Spectros, Rad. Transfer, 60 (1998), p. 665 